\title{
BODY CONDITION AND PHYSICAL CARE SCALES IN THREE CASES OF DOG HOARDING
} FROM BELGRADE

\author{
VUČINIĆ MARIJANA* and DIMITRIJEVIĆ I**
}

*Faculty of Veterinary Medicine, Department of Animal Hygiene, Belgrade

**School of Medicine, Institute for Psychiatry, Belgrade

(Received 27 April 2007)

In the spring of 2006 Belgrade city officials were planning to take steps to reduce the city's stray dog population. The plan was to sterilize (spay or neuter), microchip and vaccinate about 5000 dogs during the next two years. The plan was set to kick into action at the start of September in 2006, with a monthly goal of spaying or neutering at least 255 dogs. Taking the program one step further, approximately 15000 dog owners will be given free microchips for their dogs, among them owners of private dogs' shelters, too. A professional team of four members was formed with the aim to visit all private shelters for dogs in Belgrade. The team found three cases of dog hoarding. In all of them, hoarders claimed to possess a "no-kill" shelter for dogs. These hoarders were likely to exhibit characteristics between overwhelmed caregivers and rescuer hoarders. These cases of hoarding are described in this paper from the dog abuse aspect. The two parts of Tufts Animal Care and Condition (TACC) scales were used for this purpose (body condition and physical care scales). Body condition and physical care were evaluated in 429 dogs (220 dogs in the first, 157 dogs in the second and 52 dogs in the third hoarder). There were significant differences $(P<0.0001)$ only for body condition of dogs in three cases of hoarders. Inadequate diet was the main reason for this state. Physical care of dogs ranged from borderline to terrible without significant differences between three cases of animal hoarding.

Key words: abuse, dog, hoarding

\section{INTRODUCTION}

According to Melamed et al. (1998) collecting is a normal phenomenon, in contrast with pathological collecting, or hoarding. Animal hoarding is the excessive collection and retention of animals. Animal hoarding can jeopardize animal and human welfare and spread contagious diseases. In HARC (2002) study the hoarders' residences were characterized by extreme clutter and poor sanitation that impaired the ability to maintain functional households. Appliances and utilities were frequently nonfunctional, and animal excrements sometimes 
accumulated to an extent that the homes were unfit for human habitation. In developed countries hoarding is recognized as both a mental health issue and a public health problem. Severe hoarding may endanger not only the health and safety of the individual, but also their surrounding community (Frost et al., 2000; Kuehn, 2002). According to Kuehn (2002) veterinarians can take a lead role in solving problems related to animal hoarding. Worth and Beck (1981) published the first article on animal hoarding.

In 2002, Arluke et al. (2002) looked at 100 articles about animal hoarders published from 1995 to 2001 in the United States and Great Britain and found five primary emotional themes in the articles: drama, revulsion, sympathy, indignation, and humor. They concluded that these themes drew readers' attention and made desparate facts behind cases understandable by packaging them in familiar formats, they also presented an inconsistent picture of animal hoarding that could confuse readers about the nature and significance of this behavior as well as animal abuse, more generally.

The psychology of animal collectors was the theme of Lockwood (1994). According to Dinning (2005) hoarding is usually considered a manifestation of obsessive compulsive disorder (OCD) and may occur alone or in the context of other disorders such as dementia, schizophrenia, eating disorders, mental retardation, and obsessive-compulsive personality disorder (OCPD), social phobia and depression (Frost et al. 1996; Winsberg et al. 1999; Steketee and Frost 2003). The most difficult type of hoarding to treat is animal hoarding. As Dinning (2005) cited a hoarder may claim to be a pet rescuer thus, an effective ploy for the media or as a defense in court. Some individuals may actually enable the acquisition of animals, either by bringing them to the hoarder or encouraging others to do so: usually under the belief that they have found someone to legitimately care for needy animals (Patronek, 1999; Patronek and HARC, 2001). An animal hoarder accumulates a large number of animals, overwhelming that person's ability to provide even minimal standards of nutrition, sanitation, and veterinary care, fails to acknowledge the deteriorating condition of the animals (including disease, starvation, and even death) and household environment (severe overcrowding, very unsanitary conditions), as well as, fails to recognize the negative effect of the collection on his or her own health and well-being, and on that of other household members. Patronek (1999) found that 76 percent of animal hoarders were female; 46 percent were 60 years of age or older; most were unmarried; in 69 percent of cases animal feces and urine accumulated in the living areas; in more than 25 percent of the cases the hoarder's bed was soiled with feces or urine; in 80 percent of reported cases dead or sick animals were discovered and in 60 percent of the cases, hoarders did not acknowledge the problem. According to Dinning (2006) there are many benefits of a community response to hoarding and all of them demand cooperation of a broad spectrum of municipal agencies and social service organizations, as well as, the establishment of a coordinating body that includes representatives of public/community health, fire, police, housing, zoning, mental health, aging, adult protective services, child welfare, and animal welfare/control/veterinary organizations. Hoarding of Animals Research Consortium (HARC, 2006) together 
Acta Veterinaria (Beograd), Vol. 57. No. 5-6, 553-561, 2007.

Vučinić Marijana et al.: Body condition and physical care

with nationally recognized experts published a manual on animal hoarding. In the manual three general types of animal hoarders are described: overwhelmed caregivers, rescuer hoarders and exploiter hoarders. They stressed that this classification may be useful when considering different approaches to intervention. However, it is not definitive at this stage. Some overlap exists among the types and, at different times, a hoarder may exhibit characteristics of all three types. Also, there are two other types of hoarders: the incipient hoarder and the breeder-hoarder. The most difficult or problematic type to deal with are the exploiter hoarders. Different types of hoarders require different intervention strategies (Patronek et al. 2006). According to PETA (2005) the central issue is animal suffering, not the hoarder's intentions. Also, according to Berry et al. (2005) animal hoarding is a form of abuse that affects thousands of animals each year, yet little is known about how cases are best resolved, the effectiveness of prosecution, and how sentences relate to the severity of the offense. This lack of information has hampered effective resolution and the prevention of recidives.

\section{MATERIAL AND METHODS}

For the hoarder described in the study the modified animal hoarding case report by Dinning (2005) and a classification of HARC (2006) were used. The level of care for dogs provided by the owner was assessed according the Tufts Animal Care and Condition (TACC) scales by Patronek (2000). The Tufts Animal Condition and Care (TACC) scales consist of four parts: body condition scale, physical care scale, environmental health scale and weather safety scale. It was designed to help animal control officers, cruelty investigators, veterinarians, and others to accurately determine the condition of a potentially neglected dog, or the level of care being provided by the owner. In the study only two parts of TACC scales were used: body condition and physical care. The body condition was scored from 1 (ideal) to 5 (emaciated). The physical care was scored from 1 (adequate) to 5 (terrible). Body condition and physical care of 429 dogs were evaluated (220 dogs of the first hoarder, 157 dogs of the second hoarder and 52 dogs of the third hoarder).

The results are expressed as mean \pm SD. One-way analysis of variance (ANOVA) was applied. When the ANOVA results were significant, Tukey HSD-test was used to determine the level of significance.

\section{RESULTS AND DISSCUSION}

In the spring of 2006 Belgrade city officials were planning to take steps to reduce the city's stray dog population. The plan was to sterilize (spay or neuter), microchip and vaccinate about 5000 dogs during the next two years. The plan was set to kick into action at the start of September in 2006, with a monthly goal of spaying or neutering at least 255 dogs. Taking the program one step further, approximately 15000 dog owners will be given free microchips for their dogs among them owners of private dogs' shelters, too. The professional team of four 
members was formed with an aim to visit all private shelters for dogs in Belgrade. That team found three cases of dog hoarding. In all of these, hoarders claimed to possess a "no-kill" shelter for dogs.

In the first case a hoarder was a women about 70 years old who lived alone in a small house $11 \mathrm{~km}$ from Belgrade. She was a widow with a small pension. Her house consists of two small rooms occupied by dogs. It was severely cluttered by old inanimate objects. Her small house was very unsanitary. Due to clutter of food garbage, newspapers, other papers and old kitchen vessels the woman had difficulty to prepare food for her and the dogs and to sleep in the bed alone. She had neither a toilet nor a bathroom. Also, she stocked the collected food garbage (old bread) inside and outside her house. Her friend picked up strays from Belgrade's streets and brought in more dogs, old bread and animal bones for dogs to the hoarder. Also, the hoarder adopted diseased or injured dogs and pups for money from people who wised to abandon their pets. She had 165 adult mongrels, 15 purebreds and old dogs and 40 puppies. The hoarder stated that she loved dogs, that dogs were like children, that no else would care for them and that dogs were her only friends. The hoarder did not attempt to conceal the presence of dogs. Only a few dogs the hoarder was able to identify by name.

In the second case three women lived together in a small house of about 40 square meters in a suburban area near Belgrade. The youngest of them was about 35 years old and unemployed. Two another women were her aunts about 65 to 70 years old. Their house was surrounded with a small orchard in a very uncared status. There were no neighbors close by. Also, the two older women never left the premises and the youngest woman provided the family with all necessities. On their estate there was a great quantity of old and useless furniture and 157 dogs. The youngest woman considered their house and the surrounding land as a "no-kill" shelter for stray dogs. Also, she claimed that they were the best rescuers of animals compared to all known organizations for animal protection in Belgrade. Those three women had not enough money for support and believed that selling dogs was a good source of money for a safer life. They never sold any dog. Around their land there were numerous fresh burrows for dead dogs. Inspection of food and water for dogs estimated that they were inadequate in quality and quantity. The basic food for dogs was old bread and cooked corn meal with fat. The hoarder was able to identify only some dogs by name.

In the third case a middle-aged woman kept 52 adult mongrels in a little fenced garden. She did not live there but had a family house on the other side of Belgrade. Also, she collected old stoves, washing machines, freezers and old household furniture. Those inanimate objects served as "dog kennels". All dogs were spayed or neutered. Every day she visited the dogs and fed them with old bread, bones and cooked corn meal. The woman stated that she loved animals, as well as, members of her family. Also, she stated that no else would care for them. The hoarder was able to identify some dogs by name.

There were 30 underweight (13.64\%), 187 thin (85.00\%) and three very underweight $(1.36 \%)$ dogs in the first hoarder (Table 1). The mean value of the body condition for those 220 dogs was $2.88 \pm 0.37$. In the second case of hoarding there were 49 underweight (31.21\%) and 108 thin (68.79\%) dogs. The mean value 
Acta Veterinaria (Beograd), Vol. 57. No. 5-6, 553-561, 2007.

Vučinić Marijana et al.: Body condition and physical care

scales in three cases of dog hoarding from Belgrade

of the body condition for those 157 dogs was $2.69 \pm 0.46$. The third hoarder had 26 underweight $(50.00 \%), 23$ thin $(44.23 \%)$ and three very underweight $(5.77 \%)$ dogs. The mean value of the body condition for those 52 dogs was $2.56 \pm 0.61$.

Table 1. Body condition of dogs in three cases of hoarding

\begin{tabular}{|c|c|c|c|c|c|c|c|}
\hline \multirow{4}{*}{ Value } & \multirow{4}{*}{$\begin{array}{c}\text { Value } \\
\text { description }\end{array}$} & \multicolumn{6}{|c|}{ Case } \\
\hline & & \multicolumn{2}{|r|}{1} & & 2 & & 3 \\
\hline & & \multicolumn{6}{|c|}{ Number of dogs } \\
\hline & & $\mathrm{N}$ & Percentage & $\mathrm{N}$ & Percentage & $\mathrm{N}$ & Percentage \\
\hline 1 & Ideal & 0 & $0.00 \%$ & 0 & $0.00 \%$ & 0 & $0.00 \%$ \\
\hline 2 & Underweight & 30 & $13.64 \%$ & 49 & $31.21 \%$ & 26 & $50.00 \%$ \\
\hline 3 & Thin & 187 & $85.00 \%$ & 108 & $68.79 \%$ & 23 & $44.23 \%$ \\
\hline 4 & Very underweight & 3 & $1.36 \%$ & 0 & $0.00 \%$ & 3 & $5.77 \%$ \\
\hline 5 & Emaciated & 0 & $0.00 \%$ & 0 & $0.00 \%$ & 0 & $0.00 \%$ \\
\hline \multicolumn{2}{|r|}{$\Sigma$} & 220 & $100.00 \%$ & 157 & $100.00 \%$ & 52 & $100.00 \%$ \\
\hline & $\bar{x} \pm S D$ & \multicolumn{2}{|c|}{$2.88 \pm 0.37$} & \multicolumn{2}{|c|}{$2.69 \pm 0.46$} & \multicolumn{2}{|c|}{$2.56 \pm 0.61$} \\
\hline
\end{tabular}

One-way analysis of variance (Table 2) estimated significant differences $(P<0.0001)$ between the three cases of hoarding. The mean value of the body condition of 220 dogs in the first case $(2.88 \pm 0.37)$ significantly differed $(P<0.01)$ from the same parameter in the second $(2.69 \pm 0.46)$ and the third case $(2.56 \pm 0.61)$ of hoarding (Table 3$)$. The reason for the significant differences between investigated cases was the higher percentage of dogs evaluated as thin in the first hoarder $(85.00 \%)$ compared to the second and the third hoarders with $68.79 \%$ and $44.23 \%$ of thin dogs, respectively. In the first hoarder there were three very underweight dogs (1.36\%), as well as, in the third hoarder $(5.77 \%)$. According to Patronek (2000) in thin dogs tops of lumbar vertebrae are visible, pelvic bones became prominent and ribs are easily palpated. Minimal loss of muscle mass was evident in all thin dogs. In very underweight dogs lumbar vertebrae, pelvic bones and ribs were easily visible with moderate loss of muscle mass. There was no muscle loss in underweight dogs but, the waist was clearly visible from above. The main reason for this body status of dogs was the inadequate diet in all of three cases of hoarding.

Table 2. ANOVA for body condition of dogs

\begin{tabular}{|c|c|c|c|c|c|}
\hline Source & SS & df & MS & F & P \\
\hline \hline Treatment [between groups] & 5.9335 & 2 & 2.9668 & 15.372 & $<0.0001$ \\
\hline Error & 82.2203 & 426 & 0.193 & & \\
\hline Total & 88.1538 & 428 & & & \\
\hline
\end{tabular}


Table 3. Tukey HSD Test for body condition of dogs

\begin{tabular}{|c|c|c|c|c|}
\hline $\begin{array}{c}\text { Case of } \\
\text { hoarding }\end{array}$ & $\bar{x} \pm \mathrm{SD}$ & $\begin{array}{c}\text { Cases } \\
\text { Comparation }\end{array}$ & $\begin{array}{c}\text { Differences between } \\
\text { mean values of two cases }\end{array}$ & $\mathrm{P}$ \\
\hline \hline Case 1 & $2.88 \pm 0.37$ & Case 1:Case 2 & 0.19 & $<0.01$ \\
\hline Case 2 & $2.69 \pm 0.46$ & Case 1:Case 3 & 0.32 & $<0.01$ \\
\hline Case 3 & $2.56 \pm 0.61$ & Case 2:Case 3 & 0.13 & Non significant \\
\hline
\end{tabular}

$\mathrm{HSD}[0.05]=0.15 ; \mathrm{HSD}[0.01]=0.18$

Physical care was evaluated as borderline for 150 dogs (68.18\%), poor for 62 dogs $(28.18 \%)$ and terrible for 8 dogs (3.64\%) in the first hoarder (Table 4$)$. In the second case of hoarding 123 dogs $(78.34 \%)$ were evaluated as borderline and 34 dogs (21.66\%) as poor cases. Physical care was evaluated as borderline for 34 dogs $(65.38 \%)$ and poor for 18 dogs (34.62\%) in the third case of hoarding. There were non significant differences between three cases of hoarding for physical care of dogs. According to Patronek (2000) in dogs evaluated as borderline cases numerous mats were present in the hair, but dogs could still be groomed without a total clip down. In a large number of dogs nails were overdue for a trim and were long enough to cause dogs to alter the gait. In dogs evaluated as poor cases numerous mats were present in the coat, large chunks of hair matted together and could not be separated with a comb or brush. Long nails forced the feet into abnormal positions. In terrible cases extremely matted hair coat prevented normal motion or interfered with vision. Dogs could not be groomed without a complete clip down. Nails were extremely overgrown. There were no significant differences for physical care of dogs in the three cases of hoarding.

Table 4. Physical care of dogs in three cases of hoarding

\begin{tabular}{|c|c|c|c|c|c|c|c|}
\hline \multirow{4}{*}{ Value } & \multirow{4}{*}{$\begin{array}{c}\text { Value } \\
\text { description }\end{array}$} & \multicolumn{6}{|c|}{ Case } \\
\hline & & \multicolumn{2}{|r|}{1} & \multicolumn{2}{|r|}{2} & \multicolumn{2}{|r|}{3} \\
\hline & & \multicolumn{6}{|c|}{ Number of dogs } \\
\hline & & $\mathrm{N}$ & Percentage & $\mathrm{N}$ & Percentage & $\mathrm{N}$ & $\begin{array}{c}\text { Percent- } \\
\text { age } \\
\end{array}$ \\
\hline 1 & Adequate & 0 & $0.00 \%$ & 0 & $0.00 \%$ & 0 & $0.00 \%$ \\
\hline 2 & Lapsed & 0 & $0.00 \%$ & 0 & $0.00 \%$ & 0 & $0.00 \%$ \\
\hline 3 & Borderline & 150 & $68.18 \%$ & 123 & $78.34 \%$ & 34 & $65.38 \%$ \\
\hline 4 & Poor & 62 & $28.18 \%$ & 34 & $21.66 \%$ & 18 & $34.62 \%$ \\
\hline 5 & Terrible & 8 & $3.64 \%$ & 0 & $0.00 \%$ & 0 & $0.00 \%$ \\
\hline \multicolumn{2}{|r|}{$\Sigma$} & 220 & $100.00 \%$ & 157 & $100.00 \%$ & 52 & $100.00 \%$ \\
\hline \multicolumn{2}{|c|}{$\bar{x} \pm S D$} & \multicolumn{2}{|c|}{$3.35 \pm 0.55$} & \multicolumn{2}{|c|}{$3.22 \pm 0.41$} & \multicolumn{2}{|c|}{$3.35 \pm 0.48$} \\
\hline
\end{tabular}

Serbia has not yet a law on animal welfare or animal protection. This fact is just one of many reasons for animal hoarding ignorance. Also, there are just a few 
experts who can professionally identify an animal hoarding case. Experts for human mental disorders are not interested in animal hoarding problems. They consider that animal hoarding is a problem of veterinarians and animal protection organizations. Also they can not recognize a significance of animal hoarding problems resolving from both the animal and human welfare aspect. According to Kuehn (2002), veterinarians in Belgrade, consider animal hoarding as their problem but, they also need help from animal welfare or animal rights organizations. It is supposed that in Belgrade are at least 50 hoarding cases of dogs, cats or both animals. Also, it is supposed that many hoarders are members of unregistered associations for animal protection. On the other hand, many members of such associations protect hoarders, help, support and courage them in their hoarding activities because they can not recognize a hoarder profile. They consider that hoarders are just people who respect animals' life. Many developed countries have strategic community response to hoarding plans. A good example is "No Room to Spare" Ottawa's Community Response to Hoarding Plan prepared by Dinning in May 2006 (Dinning, 2006). Our investigation is a good confirmation for Berry et al. (2005) that animal hoarding is a problem that few people recognize as an important community concern. It seems that dogs are the most popular animals to be hoarderd in Belgrade. According to HARC (2006) hoarders described in the study were likely to exhibit characteristics between overwhelmed caregivers and rescuer hoarders.

\footnotetext{
Address for correspospondence:

Marijana Vučinić

Department of Animal Hygiene

Faculty of Veterinary Medicine,

University of Belgrade

Bulevar oslobođenja 18

11000 Belgrade, Serbia

E-mail: mery@vet.bg.ac.yu
}

\section{REFERENCES}

1. Arluke A, Frost R, Steketee G, Patronek G, Luke C, Messner E, Nathanson J, Papazian M, 2002, Press Reports of Animal Hoarding, Society and Animals, 10, 2, 113-35.

2. Berry C, Patronek G, Lockwood R, 2005, Long-term outcomes in animal hoarding cases, Animal Low, 11, 167-94.

3. Dinning BL, 2005, Animal Hoarding, In: Literature Review To Support the Development of A Community Response to Hoarding, Prepared for: The Ottawa Community Response to Hoarding Coalition, 1-32.

4. Dinning BL, 2006, Animal Hoarding Case Report Form, In: "No Room to Spare", Prepared for: The Ottawa Community Response to Hoarding Coalition, Ottawa's Community Response to Hoarding Plan, editor, Attachment $\mathrm{H}$ - Sample Assessment Form, 98 -104.

5. Frost RO, Krause MS, Steketee G, 1996, Hoarding and obsessive-compulsive symptoms, Behav Modif, 20, 1, 116-32.

6. Frost RO, Steketee G, Williams L, 2000, Hoarding: a community health problem, Health Soc Care Community, 8, 4, 229-34.

7. Hoarding of Animals Research Consortium (HARC), 2002, Health implications of animal hoarding, Health Soc Work, 27, 2, 125-36. 
8. Hoarding of Animals Research Consortium (HARC), 2006, Understanding the Animal Hoarder Types of Hoarders, In: Animal Hoarding: Structuring interdisciplinary responses to help people, animals and communities at risk, Patronek GJ, Loar L and Nathanson JN, editors, 19-20.

9. Kuehn BM, 2002, Animal hoarding: a public health problem veterinarians can take a lead role in solving, JAVMA, 221, 8, 1087-9.

10. Lockwood R, 1994, The psychology of animal collector, Trends, 9-14.

11. Melamed Y, Szor H, Barak Y, Elizur A, 1998, Hoarding--what does it mean?, Compr Psychiatry, 39, 6, 400-2.

12. Patronek GJ, 2000, Tuft's Animal Care and Condition (TACC) scales for assessing body condition, weather and environmental safety, and physical care in dogs, Can Vet J, 634-5.

13. Patronek GJ, 1999, Hoarding of Animals: An Under-Recognized Public Health Problem in a Difficult-to-Study Population, Public Health Rep, 114, 1, 81-7.

14. Patronek GJ, Hoarding of Animals Research Consortium (HARC), 2001, The problem of Animal Hoarding, Municipal Lawyer, 19, 6-9.

15. People for the Ethical Treatment of Animals (PETA), 2005, Animal Hoarding Is Cruelty to Animals, In: Animal Hoarders: Behavior, Consequences, and Appropriate Official Response, Information for Prosecutors, Judges, and Law Enforcement Agents, People for the Ethical Treatment of Animals, editor, Norfolk, 2-5.

16. Steketee G, Frost R, 2003, Compulsive Hoarding: Current Status of the Research. Clinical Psychology Review, 23, 9, 905-27.

17. Winsberg ME, Cassic KS, Koran LM, 1999, Hoarding in obsessive-compulsive disorder: a report of 20 cases, J Clin Psychiatry, 60, 9, 591-97.

18. Worth D, Beck AM, 1981, Multiple ownership of animals in New York City, Transactions \& Studies of the College of Physicians of Philadelphia, 3, 4, 280-300.

\title{
OCENJIVANJE TELESNE KONDICIJE I BRIGE O FIZIČKOM IZGLEDU PASA U TRI SLUČAJA HORDAŠENJA IZ BEOGRADA
}

\author{
VUČINIĆ MARIJANA i DIMITRIJEVIĆ I
}

\section{SADRŽAJ}

Sredinom 2006. godine nadležni organi uprave u Beogradu planirali su preuzimanje mera za smanjenje populacije pasa lutalica. Plan je podrazumevao sterilizaciju, obeležavanje mikročipovima i vakcinaciju oko 5000 pasa lutalica u Beogradu u naredne dve godine. Sprovođenje plana započelo je početkom septembra 2006. godine, a na mesečnom nivou, planom je predviđena sterilizacija 255 pasa. Uz to je planirano i obeležavanje mikročipovima oko 15000 pasa poznatih vlasnika, ali i mikročipovanje pasa u privatnim prihvatilištima. Imenovan je stručni tim od četiri člana, čiji je zadatak bio da obiđe sva privatna prihvatilišta za pse na teritoriji grada Beograda. Prilikom obilaska prihvatilišta, stručni tim je otkrio slučajeve hordašenja (patološkog kolekcioniranja) pasa. U sva tri slučaja patološki kolekcionari pasa su tvrdili da poseduju prihvatilišta za doživotni boravak pasa, takozvana no-kill prihvatilišta. Utvrđeno je da otkriveni kolekcionari ne pripa- 
Acta Veterinaria (Beograd), Vol. 57. No. 5-6, 553-561, 2007.

Vučinić Marijana et al.: Body condition and physical care

scales in three cases of dog hoarding from Belgrade

daju jednom od tri jasno diferencirana tipa patoloških kolekcionara, već da ispoljavaju osobine između takozvanih pažnjom preokupiranih kolekcionara i spasilaca životinja. Slučajevi patološkog kolekcioniranja analizirani su aspekta zapostavljanja pasa. Za u radu su iskorišćena dva dela TACC skale za procenu brige o životinjama i stanja uhranjenosti životinja. Telesna kondicija i i briga o fizičkom izgledu procenjivana je kod 429 pasa (220 kod prvog, 157 kod drugog i 52 psa kod trećeg slučaja hordašenja). Statistički značajne razlike između ova tri slučaja hordašenja utvrđene su samo za stanje uhranjenosti $(P<0,001)$. Glavni razlog za zatečeni status pasa bila je neodgovarajuća ishrana. Ocena brige o fizičkom izgledu pasa kretala se od granično prihvatljivih do krajnje neprihvatljivih slučajeva. 